\title{
Dorothy Day's Pursuit of Public Peace through Word and Action
}

\author{
GAIL M. PRESBEY \\ University of Detroit Mercy, Detroit, Michigan, USA
}

\section{Introduction}

Dorothy Day was a lay woman and journalist who, by her teens and during her college years, was an atheist attracted to communism. She converted to Catholicism after giving birth to her 3daughter, Tamar, which she interpreted as a religious experience. She was torn by how to reconcile her ideals for social justice that she had expressed in a left-wing political context with the seeming apolitical nature of the religion that she had entered. When Peter Maurin, a wandering French peasant, taught her about Catholic Social doctrine expressed in the papal encyclicals Rerum novarum (The New Reality; commonly translated into English as On the Conditions of Labor) (Leo XIII, 1891) and Quadragesimo anno (known in English as On Reconstructing the Social Order) (Pius XI, 1931), Day was heartened.

With Maurin, Day founded communities where members lived in simple poverty. Community goals included helping the less fortunate, rallying around political causes to end militarism and war, and helping the marginalized gain their rights. Drawing on the motto of the socialist and anarchist organization, Industrial Workers of the World (IWW), Maurin explained that they were going to "build the new world in the shell of the old" (Egan, 1999, p. 266). They were also motivated by Petr Kropotkin's emphasis on mutual aid. They began publishing The Catholic Worker newspaper in 1933, during the height of the Great Depression. Thus began fifty years of using the press to convey the message of their movement in addition to living their philosophy of serving the poor, standing with those were ostracized for their conscientious views, and reaching out in peace and reconciliation toward those the Church or State had labeled as its enemies.

Many of Day's public positions were controversial. During the Spanish Civil War, she did not support General Francisco Franco when most other Catholics did, and during World War II, she supported conscientious objectors who refused to fight. Day also refused to participate in Civil Defense drills during the 1950s in New York as a protest against the nuclear arms race. Instead, she would sit on a public bench in the park to voice her protest by action. During the early 1960s, she visited Cuba and tried to reconcile the Marxist-Leninists and Catholics there. Later, in the 1960s, she lent her support to inter-racial farming communities in the rural South as a step toward undoing racism in America. During each of these events, Day took a lot of risks. She faced ostracization, jail time, loss of funds for her movement, and

This is a pdf copy of the author's accepted manuscript of "Dorothy Day's Pursuit of Public Peace through Word and Action," by Gail M. Presbey. The version of record appears in Peace Philosophy and Public Life: Commitments, Crises, and Concepts for Engaged Thinking, edited by R. Greg Moses and Gail Presbey. Amsterdam: Rodopi Publishers, 2014. DOI: https://doi.org/10.1163/9789401210522 Used with permission. 
death threats. What kept her going with a cheerful heart? As she explains, her faith sustained her.

In taking unpopular stands, not only did Day articulate her views, but she followed them with actions. In each case, she articulated and circulated her message as journalist and publisher, thereby attempting to sway public opinion and encourage others to join her causes. Due to her concern for shaping public opinion, I see her as an example of a thinker and activist dedicated to encouraging public peace. Through a combination of her words (selfexpression of her beliefs, values, and commitments) and her actions (consonant with these beliefs), Day shaped public discourse and practiced her goal of lasting, "positive peace," which in Johan Galtung's terminology, is based on mutual understanding and respect, not merely on the absence of war. Day's target audience varied widely, including fellow Catholics, fellow Catholic Workers, Americans, and global citizens. She sometimes focused on challenging her faith community, and at other times focused on political communities.

In this chapter, I will focus on how Day constantly engaged the public, asking them to rethink their views and to join her in common action. I will illustrate my thesis using three examples: her role as newspaper founder and journalist, addressing the public through her writings; her protests in public places; and her founding a large associational community, which is both social and public. These three examples intersect and overlap; they are really three facets of Day's public practice of peace philosophy.

\section{Speech and Action in the Public Realm: Theoretical and Historical Context}

Before expanding on the three concrete ways in which Day engaged the public, I first want to talk about speech, action, and the public realm on a more abstract level. What is the goal of public speech and action? To call upon some of the analysis of Hannah Arendt, we can say that two important aspects of speech are, first, that it reveals the agent, and second, through speech, people reach out to each other and set up relationships. As Arendt describes it, a human act must contain the answer to the question, "Who are you?" Through our acts and speech, we reveal ourselves to our community. Our "who" is revealed in action, and we are visible to those we encounter. It takes courage to speak and act in the world because each action discloses the agent along with the act. We disclose ourselves to people unknown to us. However, although fear can be aroused in revealing oneself, so also can joy. Arendt notes that for the ancient Greeks, action in the polis was propelled by an "urge toward self-disclosure" (1958, pp. 180, 194). As she wrote in her description of Rahel Varnhagen's salons in Berlin, "the true joy of conversation consisted in being understood" (1974, p. 20).

Disclosing ourselves to each other creates the public realm. These encounters with each other create what Arendt calls the "in-between," the real world of action and speech that goes on between people. This public world is real even though it isn't comprised of objects, but rather of words, deeds, and relationships. Arendt calls the more intangible aspect of the inbetween the "web of human relationships" (1958, pp. 182-183). I suggest that Day was often busy weaving this web of relationships, connecting people to each other to build a positive peace.

Looking closely at The Human Condition, we see that Arendt describes an objective and subjective aspect to the "in-between." The objective aspect consists of matters of the world that are of interest to both parties, which is what brings them together in speech and action. But each encounter has a subjective aspect as well, the disclosure of the self (the "who") to 
one another. While the subjective aspect of the in-between is intangible and has no "end products," it is nevertheless real and important. In fact, wherever human beings live together, they create (or, better, already find themselves in) a web of human relationships that connects and constrains new action. As she explains, since this "already existing web" is so filled with "innumerable, conflicting wills and intentions," actors rarely achieve their intended purpose. While this is no doubt a frustrating aspect of our actions and relations with each other, the fringe benefit is that this dynamic of interaction makes for good stories-narratives chockfull of heroes - that may find their way into our history books. Of course, to focus on a singular "hero" usually misrepresents actions that are the results of multiple parts of the web (Arendt, 1958, pp. 182-184). According to Hanna Fenichel Pitkin, this non-material aspect of the web of relationships refers to non-material culture, in contrast to the part of the "world" created by "work" and crafting of human hands, built architecture, or works of art.

I must clarify that revealing oneself in public regarding political matters is not the same as indiscretion, that is, "uninhibited utterance," or, saying in public what should remain private (Arendt, 1974, p. 21). Arendt staunchly defended the "sanctity" of the private sphere from the glare of publicity.

Any time one draws upon the concepts of "public" and "political" as used by Arendt, there is a danger, because, it is easy to see in some of her writings, especially in The Human Condition, a reliance on Aristotelian ideas and distinctions that contemporary scholars, especially feminists, consider problematic (Honig, 1995). For example, she contrasts the public realm with a private one. In the ancient Greek examples, among others, men were to find their place in the public realm but women and their duties were found in the private sphere of the household. No doubt, the household was larger than our current American nuclear families, encompassing slaves as well as free persons, but nevertheless having as its goal the survival and reproduction of the family, while the public realm had a loftier, intangible goal of practicing public freedom.

One could not fault many readers for rejecting the continuation of these kinds of distinctions. Thus, to ensure that the relevancy of Arendt's insights is patent, I refer to her ideas as explored by Seyla Benhabib, who practices thinking "with Arendt against Arendt" (2003, pp. 6, 198), by which she means not just reinterpreting Arendt but actually revising her views. Benhabib draws upon and champions some of Arendt's ideas at the expense of others that go against her own insights.

Benhabib draws on Arendt's early work, Rahel Varnhagen, to find a different model of public space and appearance in public. Rahel Levin Varnhagen, a single woman, had operated a salon - a kind of public meeting space hosted in private houses - in her garret in Berlin from 1790 until Napoleon's invasion in 1806. Then, she left Berlin, married Von Varnhagen, and eventually came back to Berlin, re-opening a salon there from 1821 through 1832 (Arendt, 1974, pp. 229-231; Benhabib, 2000, pp. 6-7). Georg Wilhelm Friedrich Hegel, along with Rahel's close friend, the poet Heinrich Heine, frequented the salons. Rahel and others who appreciated the ideals of the Enlightenment, the French Revolution, and Napoleonic reforms to monarchy engaged in discussion in the salon (Arendt, 1974, pp. 192194). She and Heine became supporters of Saint-Simonianism, which was a utopian socialist movement that influenced the ideas of Auguste Comte, Karl Marx and John Stuart Mill. Heine finally left Berlin to go to France after the July revolution there-both he and Rahel saw the revolution as reinforcing the principle of equality and popular sovereignty over hereditary right (ibid., pp. 226-227). 
Drawing on Deborah Hertz's work (1988), Benhabib traced the history of salons in France and Germany. She noted that Varnhagen was one of several Jewish women in Berlin able to run salons. Benhabib sees the salons as providing a space for people to see and be seen and heard, both in verbal discussion and in recitals of their writing. The salons in Germany were egalitarian gathering places where people of differing ethnic backgrounds, classes, and religious background could meet each other and exchange ideas. Women such as Varnhagen herself and others who frequented her salon could escape the confines of patriarchal family tradition and be seriously heard. Anyone with talent and good ideas could receive recognition.

The "joy of conversation" at the salons was not all, or even mainly, about politics. Yet it often involved a search for "soul friends," with intimacy or "civic friendship" developing among those who gather for a common public purpose (Benhabib, 2003, pp. xi-xii, 15-17). These salons, Benhabib emphasizes, "contradict the agonal model of the public sphere" and are also important alternative models of the public that are more friendly to and inclusive of women's participation than the ancient Greek and Aristotlean models (ibid., p. 19).

Benhabib sees the salons and Arendt's study of Varnhagen's salon as piecing together an important and often neglected part of the history of modernity. The salons, undoubtedly private-public hybrids, created and kept alive public debate and exchange of ideas.

This idea of public life as a public-private hybrid that is more egalitarian than agonal politics is what comes closest to describing Dorothy Day. Her critics may quickly point out that she eschewed participation in electoral politics and other attempts to influence or shape public policy. So, in some people's eyes, she was apolitical or at least seemed to follow a conservative agenda of minimizing government. But this would clearly be a misunderstanding of her role and accomplishments. To better understand her relationship with the public, we should examine the parallels between her situation and the salons.

Day was a reporter long before she founded her own newspaper. Her earlier and repeated experience of how the written word can reach others and shape their views was the reason she decided to start her own newspaper. She was certainly not alone in this sentiment. The ability to write and publish one's own thoughts and opinions is a cornerstone of our current concept of free speech, ratified in the First Amendment to the US Constitution (1791).

Before further elaborating on examples of Day that illustrate these parallels, however, I turn to the history of advocacy newspapers, using some concrete examples that can be seen as precursors to some of the same aspects of Day's community and her actions.

A writer, while often solitary during the moment of writing, is always trying to reach a larger audience. The idea that a paper would be founded to spread ideas - not just to "neutrally" or "objectively" report the news - is longstanding. It has played an important role in political movements around the world. For instance, James Franklin of Boston published the New England Courant in 1721, which began its political crusades almost immediately. By 1722, Franklin was in jail for publishing criticisms of the colonial government (at which point his brother, Benjamin Franklin, took over the press).

When Mohandas Gandhi started the Satyagraha Movement (nonviolent resistance), he also started his newspaper, Indian Opinion. His first commune/ashram, Phoenix Settlement, founded in 1904 near Durban, housed the paper's printing press. In fact, the printing shed was the first building built; after that came simple wood and corrugated iron houses for dwellings. The ashramites lived together in simple poverty and had the task, in addition to farming, of 
writing articles, running the press, making copies, and distributing them. A farm and the free labor subsidized the newspaper (Brown, 1989, p. 42).

Day's life and the model of Day's Catholic Worker community are quite similar to Gandhi's life and the organizational structure of the ashrams. Judith Brown's in-depth study of how Gandhi began his public career shows that it was built gradually, and that there was a "gradual merging of Gandhi's 'home' and 'public' life" (ibid., p. 41). In his personal household, he rejected material comforts and possessions that would traditionally have come with someone of his class status (as a lawyer and barrister), doing his own chores.

But that was only the first step. From the individual household came the communal living experiences, first on the small 100 acre Phoenix Farm, and then in a much larger community on the 1000 acre Tolstoy Farm. Judith Brown suggests that through these communities, Gandhi's private and public life merged. He learned to found and organize political associations, gathering his constituency and recruiting volunteers as support networks (ibid., p. 47).

Similarly, Dorothy Day's newspaper does not spring up as separate or apart from her founding an association. The Catholic Worker community and the authors of the newspaper articles lived together in community and supported the paper, which otherwise brought in little revenue as it was sold to the poor for a penny a copy.

Thus, Day's role as a reporter and newspaper founder cannot be understood apart from her role as founder of an association. As with Gandhi, her founding of an association sprung gradually from changes to her private household until it incorporated many others beyond family with blood ties.

\section{Newspaper Founder and Reporter}

Before I look at the founding of the newspaper, which then gave birth to the Catholic Worker associative community, let me first look at Day's early journalism career and the background of the IWW (aka Wobblies), which played a significant role in her early assignments as a journalist.

From Day's autobiography, The Long Loneliness, we learn that from the time she was a college student, she longed to be part of a transformation of society. She wanted the world to be open to and supportive of "the lame, the halt and the blind" just as during her childhood, when she was in the San Francisco earthquake, neighbors had come to aid each other (1981, p. 39). Day began to become socially conscious at age fifteen when she read The Day Book, the newspaper for which her brother began working at that time. Aimed at the working class and sold for a penny a copy, The Day Book awakened her to people such as Eugene Debs; this was also where she learned of the IWW for the first time and where she read of the struggles of the labor movement, especially in Chicago (1981, pp. 36-37). As a university student looking for a way forward to such a world, she joined the socialists. At the time, her teachers told her that religion was a crutch for the weak, so she eschewed her religious ties. One of the first things she mentions is joining a club for writers, and one of the first articles she wrote was about her personal experience of going hungry. She had turned down jobs that seemed drudgery, and so she understood her poverty as the price of her nonconformity (ibid., p. 44). She struck up a friendship with Rayna Prohme, a Jewish woman who had been rejected from the sororities at their university due to discrimination against Jews. Day accepted Rayna's invitation to move in to the Jewish boarding house with her. 
At this time in her life, Day recalls grappling with big questions. Why not avoid social evils in the first place to reduce the need to remedy them? If fathers had good paying jobs (or were supported by disability payments should industry ruin their health), they could support their children (ibid., p. 45). For this reason, she chose a career in journalism, with the goal of exposing injustices and thereby playing a part in changing the world.

In writing her autobiography, and looking back at this earlier time in her life, Day noticed that her thoughts were that journalism - influencing others through one's writings - was the work of men, as was picketing, going to jail, and generally making a mark on the world. She saw men as the revolutionaries, whereas she thought that women were "by nature" materialistic, thinking of the home and children, and caught up with "women's work" (ibid., p. 60). She wanted to be part of this men's work, not women's work.

The first newspaper at which Day worked, The Call, was a socialist daily. She described power struggles within it, with the main forces behind them being the AFL, the IWW, the CIO, and the anarchists. She praised the IWW leadership (Bill Haywood, Joe Hill, and others). She recalled that the anarchists, inspired by Kropotkin, Leo Tolstoy, and PierreJoseph Proudhon, were too small for her to take seriously at the time. Her first assignment for The Call was to write an article on what it is like to live on five dollars a week-a typical low wage for poor workers at the time. Other newspapers were writing articles like this to send the message that it is not so hard to live frugally (and so the poor shouldn't complain). To achieve authenticity, Day experimented with her own body-finding a cheap tenement and eating as the poor did (ibid., pp. 52, 53; Miller, 1973, p. 76). Through her journalism, Day wanted to "build up a tremendous indictment against the present system"

(ibid., p. 66).

I want to take a moment to mention the important early work that the IWW did to protect free speech rights, including the right to assemble, to speak on the streets, and to publish newspapers. In Brave New Neighborhoods, Margaret Kohn pays tribute to this early work. While freedom of speech and the press was enshrined in the Constitution, it took the work and sacrifice of activists to make it a reality. For instance, the government was always willing to curtail speech during times of war, for instance, such as in the Sedition Act of 1798. Early abolitionists suffered when they printed newspapers articles popularizing their cause, such as reporting about Elijah Lovejoy, who was shot by a pro-slavery mob (Kohn, 2004, pp. 23-24).

Founded by Bill Haywood in 1905, the IWW was an anarcho-syndicalist group. For them, the right to free speech was crucial as a precondition to political and economic change. Consisting of miners, lumberjacks, and agricultural workers who considered the AFL to be a sell-out, they could not afford to rent halls to get out their message. They went street speaking. But in Spokane, Washington, the police and courts did the bidding of businesspersons who complained that such rallies blocked traffic and were a nuisance that hurt their businesses. Selective enforcement of nuisance laws was used to silence the IWW.

Despite the Supreme Court decision of 1909 upholding the Wobblies' right to speak on the streets, Spokane law enforcement continued to arrest speakers for other "crimes" such as vagrancy or disorderly conduct. The Wobblies decided to counter by filling the jails. When one speaker was arrested, another would take that person's place, until there were hundreds in the jails. The police countered by beating people in jail. Kohn notes that in one month, 681 men were brought to the emergency room for injuries sustained by beatings incurred in jails. Nonetheless, the IWW continued, its goal being to bankrupt the city with costs of imprisonment and trials. Finally, in March of 1910, Spokane agreed to honor the IWW's right 
to freedom of speech, press, and assembly. Prior to this time, the strong emphasis on the right to free speech that we now see had not yet taken deep root in American culture. This norm was gradually established through actions such as those by the IWW (Kohn, 2004, pp. 28$33)$.

After Day left The Call, she began a job writing for The Masses ("the liberals" as she identified them), which was shut down in November 1917. Soon afterward, Day accompanied a group of suffragists who protested at the White House. They were all arrested and mistreated, and in response, went on a hunger strike (Day, 1981, pp. 72-83; Miller, 1974, pp. 49-50). This was a profound experience for Day.

For a while thereafter, Day was a freelance writer. During this time, she moved to Staten Island, had a child, and converted to Catholicism. But she did not know yet how to wed her newfound spirituality with her political convictions. She took a job reporting for Commonweal, her first Catholic publication, covering those on a hunger march to Washington DC, protesting unemployment and eviction from their homes during the Depression. Day felt frustrated that Catholics were not a part of this march for change. She prayed at the National Shrine at Catholic University for guidance. Right after that, as if an answer to her prayer, she met Peter Maurin (Day, 1981, pp. 162-166).

Born in France in 1877, Maurin had emigrated to the United States and Canada. He held a personalist philosophy, melding the philosophical ideas of Nikolai Berdyaev with the Catholic papal encyclicals to come up with his own unique ideas, which he then popularized by paraphrasing them into witty "easy essays." An avid pamphleteer, Maurin would stuff his own pockets with his writings and hand them out to everyone he met (Miller, 1973, pp. 7, 22). After he met Day, he would drop by her house every day for about four months, arriving around 3 p.m., and talking incessantly while she went about the house doing her work, and only leaving when ejected around 10 or 11 p.m. During these visits, he shared with Day his philosophy as well as the influences on his thought (ibid., p. 63).

Once Maurin and Day had exchanged ideas and realized that they wanted to start a newspaper that would popularize Catholic social teaching, to be distributed on May Day in Union Square in 1933, Day used personal money to finance the first issue, which involved printing 2500 copies. She said her goal was to mitigate class conflict, not stir it up. The first issue was filled with Maurin's "Easy Essays" and Day's writings. To help the success of the first issue, after distributing it in Union Square, they mailed copies to prominent Catholics, receiving praise and endorsement from many. Within four months, they were distributing 25,000 copies, and within a few years, distribution reached 150,000 copies.

To support the newspaper, Maurin and Day started a house of hospitality to house the volunteers and workers who helped with the paper. It was modeled on the IWW "flophouses," where they fed everyone mashed potatoes. Day's apartment was on Fifteenth Street, and at first they expanded into an unused barbershop on the ground floor. Two women moved in to help with the second edition of the paper. Then they expanded into three apartments. Finally, they decided to move into a house at 144 West Charles Street. Always growing in number of residents, the Charles Street house became so crowded they had to eat in shifts. A year later, they moved into the 115 Mott Street house, with 12 rooms for women and 28 rooms for men in addition to the space to work on the paper. While they were Catholic, they used the Wobbly slogan, "to build a new society within the shell of the old" (Day, 1981, pp. 186-190, 196; Miller, 1973, pp. 99, 106-107). 
The Catholic Worker covered the plight of workers in many fields. Nancy Roberts notes that Day had honed her writing techniques in her earlier work for The Masses, "where literary brilliance had likewise illuminated radical commentary," and intended to use her skills to communicate her ideas, writing muckraking exposés with "evocative detail" (1988, pp. 121122). Day also used the paper to share spiritual commentaries, in which she commented on complex theological issues. Her style ranged from sophisticated and theoretical to unpretentious and conversational. She sometimes used "comic understatement" to make her point - and used humor generally in her life to get through difficulties (ibid., pp. 123-125).

Immediately after the success of the first issue of The Catholic Worker, Maurin attempted to organize public meetings to discuss the ideas in the paper. At first he rented a hall, the Manhattan Lyceum, which cost ten dollars for eight hours. He put down a three-dollar deposit and then asked for donations to cover the rest of the cost. After holding his events there three times, subsequent events, dubbed "clarification of thought," were held in the barber shop at Fifteenth Street during the winter of 1933-1934. Professors and distinguished priests came to lead or participate in discussion (Miller, 1973, pp. 67-68).

While the Catholic Worker houses had at first been comprised of newspaper volunteer workers, they soon began to double as houses of hospitality that hosted bread lines, precursors of today's soup kitchens. Since Day's own flat on Fifteenth Street was not large enough to house all the homeless women who came to her, with the help of two priests from Immaculate Conception parish, she found another flat for them. In doing so, her mission to feed and house the poor enlarged from the small intimate circle of family into a social and public one. Including the poor, some of whom decided to live in the community, helped them to quickly outgrow the Charles Street house. The Mott Street house's bread line (serving cottage cheese, bread, and coffee) started, according to Arthur Sheehan "in an innocuous way," but by 1937, could include five hundred men (ibid., pp. 99, 108).

The Catholic Worker community also joined street protests. When Jews were attacked by Germans in July of 1935, Day, a young student from Marquette University visiting New York, and others from the community joined a protest. Day was horrified by the level of police brutality she witnessed in the break-up of the protest (ibid., p. 102).

As Eileen Egan explained, while the extent to which Day lived the example of gospel hospitality to the poor of the city seemed extreme to some, no one could deny that it was in line with the Church's teaching. But Day's position on pacifism was controversial. Her insight into scriptures led her to see the connection between her community's works of mercy and her antiwar stance.

In 1936, during the Spanish Civil War, when the Catholic Church sided with the insurgents, led by Franco, Day remained neutral, saying that she did not approve of using force. Taking such a position irritated Father Charles E. Coughlin. In July 1937, Coughlin's Social Justice reported that Bishop Michael J. Gallagher of Detroit was worried that the Catholic Worker position on Spain and Franco was enough to make him wonder "if the thing were not downright Communism, camouflaged with Catholic paint" (ibid., p. 142).

In 1940, Day tried to get protection for Catholic conscientious objectors who did not want to serve in World War Two. She suggested that the young men must choose sides, not between nations at war, but between the world's way and Christ's way.

After the bombing of Pearl Harbor, Day wrote: 
We will print the words of Christ who is with us always, even to the end of the world. 'Love your enemies, do good to those who hate you, and pray for those who persecute and calumniate you, so that you may be children of your Father in heaven, who makes His sun to rise on the good and the evil, and sends rain on the just and unjust.' We are at war, a declared war, with Japan, Germany, and Italy. But still we can repeat Christ's words, each day, holding them close in our hearts, each month printing them in the paper. ... We are still pacifists. Our manifesto is the Sermon on the Mount, which means that we will try to be peacemakers. Speaking for many of our conscientious objectors, we will not participate in armed warfare or in making munitions, or by buying government bonds to prosecute the war, or in urging others to these efforts. . . We will try daily, hourly, to pray for an end to the war. . . . Let us add, that unless we combine this prayer with almsgiving, in giving to the least of God's children, and fasting in order that we may help feed the hungry, and penance in recognition of our share in the guilt, our prayer may become empty words. (1942)

Day continued her remarks by reiterating the willingness and duty of Catholic Worker members to tend to the sick and wounded from the war, to raise food to feed people made hungry by the war, and to engage in any other works of mercy needed, but not to aid in the fighting or in manufacture of munitions.

In the context of wartime fervor, such a stance seemed clearly unpatriotic and possibly foolish. By then, the Catholic Workers had grown to thirty houses, but some now refused to distribute the newspaper because of Day's stance on the war (Egan, 1999, p. 274). Some houses closed. Such pressures on her movement, however, did not deter her. Instead, she cooperated with the Brethren and Mennonites, historically peace churches, to run conscientious objector camps for Catholics. But it proved too difficult to keep them operating. While during World War I, there had only been between two and four Catholics achieving conscientious objector status, by World War II, there were 135 (sixty-one sentenced to prison and seventy-five that came through the camps organized by the Friends and other peace churches). She found the work, in a context of scorn and derision, so difficult that, in 1943, she retreated to six months of solitude. By 1945, there were only ten Catholic Worker houses, and circulation for the newspaper dropped from its earlier height of 160,000 to about 30,000. Still, Day continued her pacifist stand.

Was Day's pacifist stand realistic or hopelessly idealistic and out of touch with reality? She is not the first to be derided for imagining a world without war. Arendt saves some of her harshest criticism for Rahel Varnhagen when, during the 1812-1813 war between France and Russia, while Rahel's husband joined the Russian forces and she was involved in collecting clothing and money for those wounded in war, Rahel imagined a world without war. Arendt chastises Rahel harshly, saying:

It is really curious to see her behaving just as abominably as all philanthropic ladies after her time - organizing everything on the slightest pretext, bursting into tears at every benefaction, worshipping all the heroes in every single soldier; and like all such ladies concocting the same infantile pacifist programs, born of overestimation of her own experience and underestimation, in fact ignorance, of all the objective factors that make history. I have such a plan in my heart to call upon all European women to refuse ever to 
go along with war; and jointly to help all sufferers. . . Wouldn't something like that work?" (1974, p. 196)

And so also, during a much later war, did critics charge Day with being out of touch with reality when she took the pacifist stand. It is not surprising that, in the just war tradition, Catholic clergy and others staunchly dismissed her. Even William Miller, the careful biographer, scarcely conceals his disagreement with her stance. He analyzed The Catholic Worker editorials on pacifism from as early as 1933 up to the outbreak of the war and noted that the organizing of Catholic conscientious objectors started as early as 1936 . He opined that the Catholic Worker position emphasizes that wars are fought to protect business's profits and that if the people refused to fund war for private industrialist and capitalist profit, wars would cease - a view that Miller considered simplistic.

When World War II broke out, the paper carried a headline story entitled "We Are to Blame for New War in Europe," listing the causes of the war as people's "materialism, their greed, their idolatrous nationalism" (Miller, 1973, p. 161). It claimed that another war had happened because people would not learn the lessons from history. As the war continued, the newspaper suggested that the real motivation for the Allies becoming involved was "British imperialism and American profiteering" (ibid., p. 162).

But Miller believed that these causes were beside the point. In his opinion, to bemoan the values and circumstances that gave rise to the war was not helpful now that the war had started. Instead, he believed that nations needed to take swift military action to limit the war and save Jewish people from their fate. He also accused Day of reading history badly (ibid., p. 162). He did, however, note that at a certain point, Day shifted her strategy away from arguments from history, and switched to theological arguments about how God's love transcends this world and that our goal is to bring the values of heaven to earth (ibid., pp. 166-167). While he mentions that critics (it's not clear whether he counts himself among them) may not be satisfied with an appeal to otherworldly values as people are dying in the midst of war, it seems clear that he believes "history" could not support the idea of wars becoming obsolete.

Some critics of the Catholic Worker movement suggested that refusal to fight in World War II was abdicating responsibility to save the Jews. Day countered by saying that the best response to the suffering of the Jews would be to implement the Bermuda Refugee Conference suggestions for speedy resettlement of them (ibid., p. 182). The Bermuda Conference had been held in April of 1943; representatives of the Allied countries gathered to strategize and consider whether a safe haven for Jewish refugees could be found. While British and American governments insisted that the war was being fought in part to save the Jews, they nevertheless were not willing to offer any safe haven to Jews escaping persecution (PBS, n.d.).

Gandhi is also well known for questioning the war rhetoric of the Allies during World War II. He challenged countries that asked their colonies to sacrifice their lives in a war to protect freedom and democracy while keeping millions in those colonies under subjection. Nevertheless, despite the long history of subjection under British rule, after the German invasion of Poland in 1938, Gandhi agreed to give Britain India's unconditional nonviolent support. He also insisted that Jewish lives could be saved through nonviolent action. But his position was voted down by the Indian National Congress Working Committee, which instead said it would voluntarily support Britain in the war effort on the condition that Britain 
promised India independence at the end of the war. The Viceroy declined to give that promise.

This refusal led historian Rajmohan Gandhi (a grandson of Mohandas Gandhi) to note that, while Britain considered itself to be in a "life-and-death struggle," its claim of being unable to meet the Congress's reasonable demands was "not honest," since the Congress's demands were well known and major steps toward self-rule had already been taken in 1937 (2006, p. 450). British refusal to guarantee independence calls into question their fight for global "freedom and democracy," although they could fall back on the position that their colonialism was not as bad as Nazi subjugation.

Day's continued commitment to peace in a world wracked with war is often dismissed by others as being out of touch with historical reality and even rationality. Nevertheless, some historians, as well as philosophers and social scientists, insist that the way forward to a world with less, or eventually, no war, while not easy, is not impossible either. It is wrong to think that a careful study of history would dictate war's necessary continuance; such study could show the way to a nonviolent future (Bartkowski, 2013; Cabrera, 2011; Paige, 2002).

Arendt emphasized that human beings are not determined to act in the same ways that they have up to this point. Through freedom, we can bring about new political realities. She coins the term "natality" to emphasize this human capability for newness (1958, pp. 8-11, 176179). While Day could be accused of trying to willfully bring about a peace for which the world's institutions are not yet ready, we can imagine her retort might be, "If not now, when?" Her community was doing what it could to make the world ripe for such a transition.

\section{Taking to the Streets: Protesting Against Nuclear Weapons}

\section{A. Protesting Air Raid Drills}

In the 1950s, Day found herself opposing a different kind of war-the Cold War and the nuclear arms race. Government, in an attempt to ready the civilian population in case of nuclear attack, instituted Civilian Defense Drills. The idea was that people should duck into air raid shelters to save themselves in the event of nuclear attack. For Day, and for Ammon Hennacy, whom she credits with the idea for the protests, this strategy implied that nuclear war was thinkable and survivable. She very much disagreed with this presumption just as she disagreed with building ever bigger weapons of this magnitude and the skewed sense of priorities in funding weapons while the needy went without food and shelter.

To protest the arms race, Day and her followers refused to obey orders during air raid drills. Following Gandhi's methods of Satyagraha, they announced their intended refusal to cooperate with the upcoming announced drill. When the alarms sounded, they sat on park benches in front of City Hall, while others scrambled to the shelters. Consequently, she was arrested and jailed. During her trial, a judge accused her of murder for contributing to the theoretical death of three million people in New York City.

Before 1955, Day had been arrested five times, each time serving jail sentences from five to thirty days for her actions. Of course, by her actions, Day's intent was not to leave her own country vulnerable to annihilation by nuclear attack. In court in 1955, she said that the point of the drill was to instill a kind of war psychology, and: 
The main reason we make our protest, those of us from The Catholic Worker, is to do penance publicly for our sin as Americans for having been the first to make and use the atom bomb. As the priest editor of the Boston Pilot said, "This is an unconfessed sin, and as such not forgiven." We publicly confess our share in the guilt of our country, and are willing to give up our freedom by this act of civil disobedience. (1957)

Without this confession of past sin, how could the country prevent itself from repeating the same moral error, with the same moral flaw of rationalizing the destruction on utilitarian grounds?

Over the years, others joined in these protests. By 1959, 2,000 protestors had been arrested for resisting air raid drills. In 1960, the police passed over Day and other Catholic Workers, arresting others instead. By 1961, the drills were discontinued (Egan, 1999, pp. 280-281; Miller, 1973, pp. 283-286).

We see how Day's civil disobedience turns all ideas of fear and safety on their heads. Since nuclear annihilation would be so grave a catastrophe, one should do anything one can to avoid it. The arms manufacturers and war theorists insert themselves at this point, and suggest that the only way to protect oneself is to get more and bigger nuclear weapons. But however many weapons one has, they are never enough to provide security. Thus, in the end, the arms race undermines security. To suggest that one could win or even survive such a war created a false sense of security.

Instead, Day insisted, to admit our shared vulnerability with all of humanity would encourage coming to mutual agreements with our enemies to dismantle the weapons. But to step out of that cycle, to protest such taking up of arms, takes courage, not only because of personal risks such as being jailed, but because we are going against the prevailing strategy embraced by our fellow citizens.

Day's civil disobedience is a good example of what Michel Foucault described as the work of an engaged intellectual:

to question over and over again what is postulated as self-evident, to disturb people's mental habits, the way they do and think things, to dissipate what is familiar and accepted, to re-examine rules and institutions and on the basis of this reproblematization ... to participate in the formation of a political will. (1990, p. 265)

An entire industry of providing security through violent technical means was being taken for granted as inevitable and reasonably safe; Day persistently called into question all these presuppositions.

Day's sitting out in the park, refusing to go indoors during an air raid drill, making a statement with her body, is another example of her public expression of peace philosophy. Two different aspects of this action are of interest. The first is the aspect of public apology, to which Day alluded in her 1955 testimony to the court. The other is the aspect of insisting on access to a public space at a time when the military has said that public space, usually accessible, is off-limits.

B. Apologizing for Hiroshima and Nagasaki 
While Day wanted to make a public apology for the bombing of Hiroshima and Nagasaki, the US government has yet to make such an apology. Instead, our government rationalizes that it was a necessity to drop those two bombs. Oftentimes, it is the people of a country who want to apologize for the actions of their governments, even when those governments are reticent to apologize officially. A 1991 poll conducted by The New York Times, the Tokyo Broadcasting System, and CBS News found that Japanese and American views of the war and the bombs were quite different:

Eighty-three percent of Japanese said that the dropping of atom bombs on Hiroshima and Nagasaki at the end of the war was morally wrong, and 73 percent said that the United States should apologize with only 16 percent of Americans favoring an apology. The proportion of Americans who would favor apologizing for Hiroshima rose to a total of 50 percent if Japan apologized for Pearl Harbor, however. (Weisman, 1991)

The CBS News study uncovered dissatisfaction among some people of both countries because neither government had apologized for its actions. (Interestingly, journalist Matthew LaPlant tells us that Lennox Tierney, an aide to US General Douglas MacArthur, said that he had witnessed Japanese Emperor Hirohito attempt to apologize for Pearl Harbor, but Hirohito was rebuffed by MacArthur [2006].)

Recently, US President Barack Obama delivered a speech on nonproliferation of nuclear weapons in Prague (5 April 2009) and he planned to visit Japan in November 2010. This led some anti-nuclear activists in Japan and abroad to have raised hopes that perhaps he would apologize for bombing Hiroshima and Nagasaki. But this was never the plan. To avoid raised expectations, Vice Foreign Minister Mitoji Yabunaka suggested that Obama focus his visit on Tokyo. These details were mentioned in a cable from US Ambassador to Japan, John Roos, to Secretary of State Hilary Clinton dated 9 September 2009.

Yabunaka's cable ended up being one of those posted on the Internet by Wikileaks. However, this cable was misunderstood and willfully misquoted by right wing news media sources. Investors Business Daily commented on the cable, wrongfully attributing to Obama and his administration the desire to apologize. The story was picked up by Rush Limbaugh, Fox News' Fox and Friends, and other commentators, who castigated Obama for daring to apologize for the bombings and satirized him by calling him "Apologizer in Chief" (Rudman, 2011).

With these attitudes regarding refusal to apologize still in place over sixty-five years after the bombing, it becomes clearer how Day's insistence on making apology as early as 1955 was such a minority position. Significantly, however, Roos finally attended the annual Hiroshima-Nagasaki commemoration during its sixty-fifth anniversary in 2010 (McCurry, 2010).

According to just war theory, bombing civilians at Hiroshima and Nagasaki violated the criteria of discrimination (targeting only combatants). While the Nazis stood trial for war crimes in Nuremberg, the Allies were never asked to stand trial for their war crimes.

Trudy Govier's philosophical analysis of forgiveness and reconciliation, entitled Taking Wrongs Seriously, explains the importance of acknowledgment of wrong and apology. Victims and perpetrators have to live together in the aftermath of conflict. If there is no acknowledgment of wrongdoing, victims feel acutely vulnerable to a similar attack in future. 
Ability to deny wrongdoing is related to impunity, a precursor of more wrongdoing (2006, p. 59). As Govier explains, calls for acknowledgement are:

calls for those responsible for committing such wrongs to recognize and admit having done so, and to articulate or represent that admission in a public forum so that it becomes an enduring part of the public history of

the state and society. (Ibid., p. 48)

Acknowledgement can be contrasted with denial, but denial can take several forms. While denial is sometimes a form of deception or lying, it is often based, rather, on selective attention, that is, ignoring uncomfortable truths (ibid., p. 49). Sometimes the goal of this deception is self-deception - coming up with a story about ourselves that is more comfortable to us. Ignoring our having seriously wronged others is morally culpable, however, because it helps us to deny our obligations to those who have been harmed (ibid., p. 52).

In the current example, the fact of the United States having dropped the bomb is not in dispute, but its moral wrongness is. The current American position denies that dropping the bomb was wrong. This shows moral callousness to the Japanese people and makes the world a more dangerous place because a superpower that does not repent for having dropped indiscriminate bombs in the past may decide to drop more bombs in the future.

While Day did not begin her air raid protests until 1955, she had repented personally and publicly for dropping the atomic bombs soon after they were dropped. In September 1945, she wrote of her horror at President Harry Truman's jubilation over the killing of hundreds of thousands of Japanese, as reported by the Herald Tribune. Of the dead so thoroughly obliterated she wrote:

It is hoped that they are vaporized, our Japanese brothers, scattered, men, women, and babies, to the four winds, over the seven seas. Perhaps we will breathe their dust into our nostrils, feel them in the fog of New York in our faces, feel them in the rain on the hills of Easton. Jubilate Deo. President Truman was jubilant. We have created. We have created destruction. (1992, pp. 266-67)

By November 1945, she was writing:

we can only suggest one thing-destroy the two billion dollars' worth of equipment that was built to make the atomic bomb; destroy all the formulas; put on sackcloth and ashes, weep and repent. (Ibid., p. 270)

Many Americans surveyed in 1991 were hesitant to apologize for the dropping of the atomic bomb on Hiroshima (at least 135,000 killed) and Nagasaki (at least 50,000 killed) unless the Japanese first apologized for Pearl Harbor (in which 2,402 American servicemen and possibly up to 100 civilians were killed) (Cleary et al., 2003; USSWestVirginia.org, 2000-2013; McCurrey, 2010). Day had a different response to Pearl Harbor. She suggested that we not respond with "vengeance" to the attack. She always tried to put the attack in perspective. She said that there are many Pearl Harbors every day, both abroad and at home. She referred to a recent event where a Black man was shot and dragged behind a car by a mob 
and set alight while still alive. Yet many Americans expected that suffering Blacks would rise above aggressive feelings and be pacifists. While she herself preferred nonviolent struggles against injustice, she highlighted the double standards of white Americans who would ask others to forego feelings of resentment and revenge while indulging in those feelings themselves.

Day toured southern states during 1943 and recounted the racism and poverty she saw there. In one instance, she witnessed a family of twenty-two people living in two rooms. She heard an account of a white man who had killed seven blacks for "insolent" behavior. She wrote, "Are not these sins crying to heaven for vengeance? ... And how can we do anything but howl over these sins in which we share? ... We share in the guilt of such cruelty and injustice" (Miller, 1973, p.180). Along the same line of thought, The Catholic Worker quoted a conscientious objector who, when asked what should be done about Pearl Harbor stated, "forget Pearl Harbor," and went on to list a series of reforms that Americans should undergo, including ending discrimination against Asians (ibid., pp. 181-82).

In these examples, Day shows keen understanding of human psychology. As Govier explains, all of us are some mixture of victim and perpetrator in the different roles we play in our lives. No person can be reduced to any particular act they commit during their lifetime. And yet there is a tendency for some to insist on their pure victimhood, seeing their opponents as nothing but perpetrators. These categories can be over-simplifying and reductionistic and may encourage polarized thinking. The emphasis on being nothing but a victim could lead to moral arrogance if the victim focuses on the undeserved harm while ignoring the larger context. Clinging to a feeling of injury and grievance may make it hard to reach out in reconciliation. This insight is not intended to encourage callousness toward victims, but rather to rule out an often unrealistic self-perception that can be counterproductive when it comes to reconciliation (2006, pp. 27-30).

In the context described above, Day is talking to Americans who see the United States as an innocent victim attacked out of the blue at Pearl Harbor. Nurturing this sense of victimhood, citizens are primed to attack in retaliation. But Day claimed that the victim is also a perpetrator, complicating the narrative by addressing uncomfortable truths about the country. She pointed to the race and class war within the United States. In this war, many Americans are perpetrators as well as victims. This complicates the American self-identity as innocents and do-gooders. Many Americans want blacks to forego vengeance. Foregoing vengeance is a good thing, but not as a double standard, and not as an excuse for tolerating injustice. A consistent ethic would involve addressing race and class injustice at home while seeking peace abroad.

What is the role of apology? No doubt apology has different connotations across cultures. While the word "apology" has several meanings, Govier focuses on the serious moral apology. Such an apology does not seek to justify or excuse one's actions, but instead clearly admits wrongdoing and accepts moral responsibility for having committed the acts. Apology involves expression of sorrow and promises to not repeat the acts and to make amends.

Collective apologies are complex in that the collective has to agree upon the substance of the apology, and then have the apology delivered by a spokesperson. Govier emphasizes that the sincerity of such apologies is based on active follow-up of commitments rather than demonstration of emotion (2006, pp. 68-69, 74-75).

Sometimes government officials do not acknowledge or apologize, but individuals do, in a way that can still bring satisfaction to victims. Govier recounts the case of two Serb 
perpetrators of the Srebrenica massacre confessing before the international tribunal at The Hague. While the official Serb leadership did not confess, and while the perpetrators did not apologize, Emir Suljagic nevertheless felt great relief, saying: "We Bosnian Muslims no longer have to prove we were victims" (Suljagic, 2003, quoted in Govier, 2006, p. 56).

\section{Public Action: Politics in the Parks}

The second public aspect of Day's civil defense drill protests was the aspect of insisting on using public space even during a time of heightened military activity. The park bench in Manhattan where Day staged her protests was just a few blocks away from the current Zuccotti Park (formerly Liberty Plaza), which is recently famous for being the temporary home of the Occupy Wall Street movement. Occupy protestors moved into the park in September 2011. The park is privately owned by Brookfield Office Properties, but is open to the public. It was chosen by the Occupy movement's Tactical Committee, which had engaged in a series of experiments to see whether occupying a park in southern Manhattan near Wall Street would be possible.

After being thrown out of Tompkins Square Park at dusk by police, and after finding Chase Manhattan Plaza barricaded, they found Zuccotti Park to be suitable to their needs as a feasible site (Writers for the 99\%, 2012, pp. 12-13). While the New York City Police Department agreed that the park was supposed to be open to the public twenty-four hours a day, they eventually cited concerns for sanitation and worries that the park's stated recreational purpose was made impossible by the presence of Occupy protestors. The city finally ousted the protestors from the park on 15 November 2011. Protestors have since attempted to re-occupy the park on several occasions, insisting that they have a right to free speech and assembly and that they should not be ejected from the park, which is their civic space. Mayor Michael Bloomberg issued a statement that read: "The First Amendment protects speech-it does not protect the use of tents and sleeping bags to take over a public space" (Wells and Walker, 2011).

Occupy movements have sprung up in other cities across the United States. These are contemporary examples of what Day's Catholic Worker communities did. People live together in poverty and simplicity, in order to pool their energies to get out a message, criticize the government, and raise issues regarding the environment, homelessness, evictions, racism, war, and other injustices. These protesters have been holding general assemblies where all are heard with respect. In addition to taking over public parks, they have moved into abandoned buildings and invited others to join them there.

Occupy Detroit, which began in a city park in October of 2011, was tolerated by Detroit police, who gave them a permit to camp overnight. But the permit expired just before Thanksgiving; occupiers agreed to clear the park just before crowds showed up for the Thanksgiving Parade - in part because cold weather was making continued camping difficult. Activists continued to live in community at a donated building at 5900 Michigan Avenue and several houses that are part of the Goldengate Restoration Project, where they rehabilitated abandoned buildings creatively, using recycled materials, such as creating "stained glass effect," making windows out of cob clay and recycled bottles (Shelley, 2011).

As of February 2013, only a small handful of Occupy protestors continue to live in community with the homeless at Goldengate, but their movement is active in protests to prevent foreclosures in the Detroit area. Food at their events is supplied by the IWW 
"Wobblies" Kitchen, which, according to their website, "[has] been ensuring Occupy Detroit participants are the best fed activists in Detroit" (http://www.occupy-detroit.us). Thus, the connection to IWW values of free speech continues today.

Since the time of Day's protests, the rights of people to access public parks to make political statements have been narrowed by court decisions. Many protestors feel that their rights to free speech are curtailed and denied. Margaret Kohn gives an overview of such legal changes and challenges, noting how much these privately owned, seemingly public spaces (like Zuccotti Park) are changing the landscape in contemporary America. Understandably, many protests want to locate themselves downtown where they will be noticed. But government officials have constructed "free speech zones," often at a distance from where protestors would prefer to be, and have set up "speech free zones" where shoppers and workers, but not protestors, are allowed. While, in 1957, the US Supreme Court ruled that free speech on campuses contributes to democratic governance, individual campuses have set up "free speech zones" in obscure areas so as not to impede "foot traffic" (Kohn, 2004, pp. 38-41).

The 1990 Supreme Court decision in U.S. v. Kokinda ruled that since a sidewalk in front of a post office was not a "traditional public forum," protestors did not have the right to gather there. Likewise, in Lee v. Krishna Consciousness in 1992, courts ruled that airports are not public spaces. Even if governments own airports, the government acts as a proprietor on the premises of an airport, not a lawmaker, and so free speech is not protected there. These cases lead Kohn to ask, in our world today where lifestyles are such that people drive their cars from suburban homes into parking garages, when do Americans ever visit the "traditional public forum" to have their views challenged by new perspectives?

An even more recent 2000 Supreme Court case, Hill v. Colorado, upheld a state statute protecting the public from unwanted communication, saying that leaflet distributers could not come within eight feet of the public to pass out their leaflets without prior consent - in effect banning leafleting even in public, according to Kohn (2004, pp. 42, 48-52). Gone are the days, it seems, of the pamphleteering Peter Maurin, or Catholic Workers, as Miller describes, "who would thrust the Worker pell-mell into whatever hand would receive it" (1973, p. 72). However, the persistence of Occupy movement protestors engaging in acts of civil disobedience is arguably a continuation of practices begun by Day, who sat in City Hall Park when the law and current war ideology said she should be in a bunker.

\section{Challenging the Catholic Church to Condemn Nuclear Weapons}

Day not only criticized her government's use of and support of nuclear weapons as a viable war strategy, she also criticized her Church's seeming tolerance of a government's choice to stockpile and threaten to use such weapons. She took an Italian ship to attend Vatican II. While on board, she had a chance to influence thirty-five bishops. After arrival, led by Gandhian Lanza del Vasto (a.k.a. "Shantidas"), Day and eighteen others fasted for ten days. The Second Vatican Council's Gaudium et Spes (Joy and Hope, often translated into English as The Church in the Modern World) said:

Any act of war aimed indiscriminately at the destruction of entire cities or extensive areas along with their population is a crime against God and man himself. It merits unequivocal condemnation. (Paul VI, § 80) 
The group wanted nuclear weapons condemned and conscientious objection for Catholics upheld. To a large extent, they got their wishes. Egan reports that Day's spirits were buoyed by the Vatican's condemnation of nuclear weapons (1999, pp. 291-294). Commenting in 1965, Day said:

It seems to me that those of the hierarchy who opposed . . . this condemnation of nuclear war were leaving out of account Divine Providence, when they thought that without these weapons of destruction we could not face up to the threat of Communism's taking over the world.

\section{Day's Critique of the Church's Anti-Communism}

While Day chose to leave socialistic movements for change, she had much respect for their dedication to just causes and felt that their movements and hers shared much common ground. As a peacemaker, she wanted to build bridges rather than denounce other movements. She rejected staying in a slot in which other members of the Catholic Church would have liked her movement to stay - the alternative to communism that could be considered anti-communism (Miller, 1973, pp. 72-74). Papal encyclicals abounded with criticisms of both capitalism and communism, but in the polarized Cold War United States, immigrant Catholic communities tended to focus only upon the evils of communism.

In the spirit of reconciling with one's political enemies, Day traveled to Cuba as a journalist in 1962, during a time when the Cubans and their form of government and economy were considered to be enemies of the United States. Many Catholics who fled Cuba to settle in Florida were big critics of the new Fidel Castro regime. Most Cuban Catholics thought they had a moral duty to try to emigrate and Day's trip to Cuba was not popular among Catholics generally. While there, she tried to encourage Catholics and Marxists to find a common ground and work together, rather than highlighting their differences. Instead of gathering in homes to discuss their opposition to the revolution, she advocated that Catholics gather to study scripture, theology and social justice. She brought them a copy of Emmanuel Mounier's Be Not Afraid (1954). Mounier was a personalist philosopher from France who had heavily influenced Peter Maurin. In his book, Mounier argued, "Modern Christianity is dangerously allied to capitalist and bourgeois Liberalism" (1954, p. 170).

Mounier believed that getting caught up in scrupulous concern for individual morality was a shortcoming of contemporary Catholic piety. Instead, he emphasized the need for Catholics to be activists, and he re-coined a popular phrase: "The moral revolution will be economic or there will be no revolution. The economic revolution will be moral or nothing" (ibid., p. 115). With such a philosophy, one would think that Catholics in Communist Cuba were well-placed for an experiment in moral revolution.

In her writing, Day shared some of the quandaries that she found among Catholics in Cuba. They were unsure whether they should send their children to school if they would learn about Marxism-Leninism there. Day told such families to have faith in God and not to worry that their religious framework could collapse so easily by exposure to an alternative. She also asked them to "find concordances as our own Holy Father has urged, rather than to seek out heresies, to work as far as one could with the revolution" (1962). She followed with a concrete example of where Catholics and Marxist-Leninists could find common ground, 
which was also an issue on which they could distinguish themselves. She suggested that Catholics could sing all verses of "The Internationale" except the verse that says there is no God or savior. During that verse, they should sit down in protest, but arise and sing along with others all the other verses:

There is the singing of the Internationale, for instance, most of the verses of which can be joined in with enthusiasm. "Arise, poor of the world/ On your feet slaves without bread/ and let us shout all together/ All united, Long live the Internationale. 2. Let us remove all shackles/ that tie humanity /let us change the face of the earth. ... This is a rough translation which a Catholic mother gave me, who said wistfully, "We could well sing the other verses. We ourselves have been ashamed of our position in the face of poverty and ignorance, of not having done more about it." (Ibid.)

Day's outreach to the Cubans in her effort to repair the damage of the Cold War and the tension between her nation and the USSR within the tenets of her Catholic religion is a clear case of attempting to build webs of relationships, where people can speak and be heard, and come to mutual understanding. She did not naively think that it would be easy to make common cause with the communists, but she thought that Catholics had better live out their faith in that way that gives witness to its truth. When authorities in Cuba told her that they believed that the imperialistic, militaristic, and capitalistic US government would not let her share her experiences of Cuba with other groups, she insisted that she would be able to do so. Indeed, she did do so during a long series of speaking engagements at parishes. But she also believed that the oppositional speech of the Cubans who worked for the Ministry of Foreign Affairs in labeling the American government as "imperialistic" was not helpful. She reflected on the need to choose one's words carefully, "that I will evoke in others what is really there to be evoked--a desire to do what is right, to follow conscience, to love one's brother and find what there is of God in every man" (1962).

\section{Conclusion}

Dorothy Day reflected on her close calls with death. She had travelled south to Americus, Georgia to be in solidarity with folks at Koinonia Farm. The farm was a racially integrated community and had come under criticism and attack by its neighbors for its practice of racial harmony. Day had volunteered to serve on a night watch to deter vandalism of the property. A car driving by in the middle of the night fired shots at her and another community member, narrowly missing them. About that event she wrote, "It is strange how the fear always comes afterward" (1968). She also spoke of the bravery needed to go into town where shop owners would call them names and ostracize them.

How is this and similar fear overcome? Day explains:

When you're with a group, when there's a whole night of singing, in the churches, on the streets, in the prisons, the very act of singing produces a tremendous courage and all fear evaporates. You can walk on the picket line and though you are conscious of the terrible hostility around you and there is a wrecked building across the way and a whole vacant lot is filled with bricks, handy for a battle, you have this sense of courage. Why? Because you have prayed for it; and because you are with others. (1968) 
Day is someone who, recognizing tensions in the community or lines of hostility drawn, whether they were lines of racial hostility or communist versus anti-communist or the wellto-do versus the have-nots, wanted to cross the chasm between the sides and weave together these human relationships in a way that would support peace and healing, not war and division. She brought people together to listen to each other (in her kitchen, or in a church, or in the park), discuss plans and perspectives, and act together to change our world for the better.

When Day died on 29 November 1980, not a single Catholic bishop attended her Requiem Mass. But the Roman Catholic Church's attitude toward her has changed over time. The Claretian Missionaries began promoting the cause for Day's canonization in 1983, and she was awarded a Courage of Conscience Award by the Peace Abbey in 1992. In 2000, John Joseph Cardinal O'Conner of New York took the first official steps toward her canonization, and she is thus called "Servant of God, on her way to Beatification which would be the next step in the process" (Anderson, 1997, p. 10). In November 2012, upon the recommendation of Timothy M. Cardinal Dolan of the Archdiocese of New York, the United States Conference of Catholic Bishops voted unanimously to move forward with the canonization process (Sharon Otterman, "In Hero of the Catholic Left, a Conservative Cardinal Sees a Saint," New York Times, 26 November 2012).

We need not believe that Day is a saint or have her canonized as a saint in order for us to take her life's message seriously. Nevertheless, that the Catholic Church is taking the sainthood process seriously is a good sign. Having her being counted among those that the Church recognizes as saints would reinforce the idea that we should model our lives after Day's insight and courage, and find our voices as she found hers.

\section{References}

Anderson, George M. (1997) “Dorothy Day Centenary,” America, November 29, 1997, 8-10, quote p. 10.

Arendt, Hannah (1958). The Human Condition, Chicago: University of Chicago Press.

Bartkowski, Maciej J.(2013) Recovering Nonviolent History: Civil Resistance in Liberation Struggles Boulder, CO: Lynne Rienner Publishers.

BBC, "File Fact: Hiroshima and Nagasaki," World War Two People's War, http://www.bbc.co.uk/history/ww2peopleswar/timeline/factfiles/nonflash/a6652262.s html (accessed January 4, 2013).

Benhabib, Seyla (2003) The Reluctant Modernism of Hannah Arendt. New Edition. Lanham, Boulder, New York: Rowman and Littlefield Publishers, Inc.

Brown, Judith M. (1989) Gandhi: Prisoner of Hope New Haven and London: Yale University Press.

Cabrera, Luis (Ed.). (2011) Global Governance, Global Government: Institutional Visions for an Evolving World System Albany, NY: SUNY Press.

Coles, Robert (1987) Dorothy Day: A Radical Devotion New York: Addison-Wesley Publishing Co.

Day, Dorothy. (1942) "Our Country Passes from Undeclared War to Declared War: We Continue our Christian Pacifist Stand," The Catholic Worker January, 1, 4. http://www.catholicworker.org/dorothyday/daytext.cfm?TextID=868 (accessed January 5, 2013) 
Day, Dorothy (1952/1981). The Long Loneliness: An Autobiography New York: Harper and Row.

Day, Dorothy (1957) "On Pilgrimage - July/August 1957" By The Catholic Worker, JulyAugust, 1, 3.

Day, Dorothy. (1962) "On Pilgrimage In Cuba: Part III," The Catholic Worker, November, 1, $3,4,6,8$.

Day, Dorothy. (1965) “On Pilgrimage - December 1965,” The Catholic Worker, December, $1,2,7$.

Day, Dorothy. (1968) "Fear in Our Time," Catholic Worker April (Document \#253). http://www.catholicworker.org/dorothyday/daytext.cfm?TextID=253

Day, Dorothy. (1992). Dorothy Day: Selected Writings. Robert Ellsberg (Ed). Maryknoll, NY: Orbis.

Egan, Eileen. (1999) Peace Be With You: Justified Warfare or the Way of Nonviolence. Maryknoll, NY: Orbis Press.

Foucault, Michel. (1990) "The Concern for Truth," in Michael Foucault: Politics, Philosophy Culture: Interviews and Other Writings, 1977-1984, edited by Lawrence Kritzman. New York: Routledge.

Gandhi, Rajmohan. (2006) Mohandas: A True Story of a Man, His People and an Empire New Delhi: Penguin.

Govier, Trudy. (2006) Taking Wrongs Seriously: Acknowledgment, Reconciliation, and the Politics of Sustainable Peace Amherst, NY: Humanity Books.

Hertz, Deborah (1988), Jewish High Society in Old Regime Berlin (New Haven: Yale University Press).

Heyer, Kristin E. (2006) Prophetic and Public: The Social Witness of U.S. Catholicism Washington, D.C.: Georgetown University Press.

Honig, Bonnie (1995) Feminist Interpretations of Hannah Arendt University Park, PA: Pennsylvania State University Press.

Kohn, Margaret (2004). Brave New Neighborhoods: The Privatization of Public Space. New York and London: Routledge.

LaPlante, Matthew. (2006) "MacArthur Aide: U.S. Must Learn from Errors," Salt Lake Tribune December 7, http://www.sltrib.com/ci_4794305 (accessed January 4, 2013).

McCurry, Justin (2010). "John Roos is first US representative to attend Hiroshima memorial ceremony in Japan," Guardian UK August 6,

http://www.guardian.co.uk/world/2010/aug/06/john-roos-us-attends-hiroshima-japan (accessed January 5, 2013).

Miller, William D. (1973) A Harsh and Dreadful Love: Dorothy Day and the Catholic Worker Movement. New York: Liveright.

Miller, William D. (1982) Dorothy Day: A Biography San Francisco: Harper and Row.

Mounier, Emmanuel. (1954) Be Not Afraid, Harper and Brothers.

Occupy Detroit website (2013), www.occupy-detroit.us (accessed Jan. 22, 2013).

Otterman, Sharon. (2012) "In Hero of the Catholic Left, a Conservative Cardinal Sees a Saint," New York Times November 26, A1.

Paige, Glenn D. (2002), Nonkilling Global Political Science New Delhi: Gandhi Media Centre.

Pastoral Constitution on the Church in the Modern World, Gaudium et Spes, Promulgated by His Holiness Pope Paul VI on December 7, 1965, section 80. 
PBS (Public Broadcasting Service), "The Bermuda Conference, (April 19 - 29, 1943)" The American Experience: Americans and the Holocaust http://www.pbs.org/wgbh/amex/holocaust/peopleevents/pandeAMEX89.html (accessed January 4, 2013).

Pitkin, Hanna Fenichel. (1995) "Conformism, Housekeeping, and the Attack of the Blob: The Origins of Hannah Arendt's Concept of the Social," in Bonnie Honig, (1995) Feminist Interpretations of Hannah Arendt University Park, PA: Pennsylvania State University Press, 51-82.

Roberts Nancy L. (1988) "Dorothy Day: Editor and Advocacy Journalist," in Patrick G. Coy (Ed.), Revolution of the Heart: Essays on the Catholic Worker Philadelphia, PA: New Society Publishers, 115-133.

Rudman, Chelsea (2011), "Right-Wing Media Hype False Story About Obama's 'Apology' For Hiroshima," Media Matters for America October 13, http://mediamatters.org/research/2011/10/13/right-wing-media-hype-false-storyabout-obamas/150115 (Accessed 1-4-2013).

U.S.S. West Virginia.org, "Full Pearl Harbor Casualty List," http://www.usswestvirginia.org/ph/phlist.php

Weisman, Steven R. (1991) "Pearl Harbor Remembered," New York Times December 8. http://www.nytimes.com/1991/12/08/world/pearl-harbor-remembered-japanese-thinkthey-owe-apology-are-owed-one-war-poll.html (accessed January 4, 2013).

Wells, Matt and Peter Walker. (2011) "Occupy Wall Street: Police Evict Protestors - as it happened," Guardian UK, November 15, http://www.guardian.co.uk/news/blog/2011/nov/15/occupy-wall-street-police-actionlive (accessed January 4, 2013). 